\title{
Effects of ethanolic extract of Irvingia gabonensis on the liver of progesterone induced obesity in female Swiss mice
}

\author{
Adesanya, O.A. ${ }^{1}$, Senuga T.O. ${ }^{1}$, Oyenike M.A. ${ }^{2}$, Adam M.A. ${ }^{3}$, Adeoye A.O. ${ }^{3}$, Shittu L.A.J. ${ }^{4}$
}

\begin{abstract}
s
Objective: The study was designed to investigate the effects of Irvingia gabonensis ethanolic extract (IGE) on the liver and lipid profile of progesterone induced obesity in female swiss mice.
\end{abstract}

Methods: Fifteen female mice weighing between 20-25g were randomly divided into three groups with each group comprising of five mice. Obesity was induced by giving the test animals progesterone $(10 \mathrm{ml} / \mathrm{kgbw})$ subcutaneously at the dorsal neck region. The groups were divided as Group A- obesity controlled + diluent $(10 \mathrm{ml} / \mathrm{kgbw})$, B- obese induced + Low dose IGE $(5 \mathrm{ml} / \mathrm{kg} \mathrm{bw})$ and C- obesity induced + high dose IGE $(10 \mathrm{ml} / \mathrm{kg} \mathrm{bw})$. After 14 days of treatments, blood samples were collected centrifuged and lipid profile levels Cholesterol, HDL, LDL and Triglyceride concentrations were estimated in the serum. The liver, peri-ovarian fat, ovary and uterus were removed from each of the mice and weighed with a sensitive balance and liver prepared for histological examinations and evaluation.

Results: Preliminary phytochemical analysis of the extract revealed the presence of glycosides. Obesity induction caused some fatty changes in the liver hepatocytes and the IGE treatment caused reduction of the fat globules around the hepatocyte with focal necrosis. The cholesterol and triglyceride level was higher in the low dose IGE treated but does not differ significantly from the high dose IGE treated and control $(\mathrm{P}<0.05)$.

Conclusion: The ethanolic extract of Irvingia gabonensis at doses studied caused a reduction in the body weight in mice which is very obvious at the low dose, while the lipid profile and the blood parameters were not affected. Hence, it may be a safe herb at doses considered. The extracts caused a significant change in the liver histology which was evident by reduction of fat globules and focal necrosis, swelling of cells.

Keywords: Progesterone, Induced Obesity, Irvingia gabonensis, Blood parameters, Lipid Profile.

\author{
*Corresponding author \\ Adesanya, O.A. \\ http://orcid.org/0000-0002-9960-399X \\ Email: oaesanya@gmail.com
}

\footnotetext{
${ }^{1}$ Department of Anatomy, Faculty of Basic Medical Sciences, Olabisi Onabanjo University, Ikenne Campus, Nigeria ${ }^{2}$ Department of Medical laboratory Sciences, College of Health Sciences, Ladoke Akintola University, Mercy Land, Osogbo, Nigeria.

3Department of Anatomy, Faculty of Biomedical Sciences, Kampala International University, Western Campus, Ishaka, Uganda.

4Department of Anatomcal Sciences, University of Abuja, Gwagwalada, Abuja, Nigeria.
} 


\title{
Effets de l'extrait éthanolique d'irvingia gabonensis sur le foie de souris suisses chez l'obésité induite par la progesterone
}

\author{
Adesanya, O.A. ${ }^{1}$, Senuga T.O. ${ }^{1}$, Oyenike M.A. ${ }^{2}$, Adam M.A. ${ }^{3}$, Adeoye A.O. ${ }^{3}$, Shittu L.A.J. ${ }^{4}$ \\ Résumé \\ Objectif de l'étude: L'étude visait à examiner les effets de l'extrait éthanoïque d' Irvingiagabonensis \\ (EIG) sur le foie et le profil lipidique de l'obésité induite par la progestérone chez la souris femelle suisse.
}

Méthode de l'étude: Quinze (15) souris femelles pesant entre 20 et $25 \mathrm{~g}$ ont été divisées au hasard en trois groupes, chaque groupe comprenant cinq souris. L'obésité a été induite en donnant aux animaux d'essai de la progestérone $(10 \mathrm{ml} / \mathrm{kgbw})$ par voie sous-cutanée au niveau de la nuque dorsale. Les groupes ont été divisés en groupes A contrôlés contre l'obésité + diluant $(10 \mathrm{ml} / \mathrm{kgbw})$, B induits par l'obésité + faible dose(EIG) $(5 \mathrm{ml} / \mathrm{kgbw})$ et $\mathrm{C}$ induits par l'obésité + dose élevée EIG $(10 \mathrm{ml} / \mathrm{kgbw})$. Après 14 jours de traitement, les échantillons de sang ont été prélevés, centrifugés et les niveaux du profil lipidique ont été estimés dans le sérum. Les concentrations de cholestérol, HDL, LDL et Triglycérides ont été estimées. Le foie, la graisse péri-ovarienne, les ovaires et l'utérus ont été prélevés chez chacune des souris et pesés avec une balance sensible et le foie préparé pour les examens histologiques et l'évaluation.

Résultats : Une analyse photochimique préliminaire de l'extrait a révélé la présence de glycosides. L'induction de l'obésité a provoqué des modifications grasses dans les hépatocytes du foie et le traitement par EIG a entraîné une réduction des globules graisseux autour de l'hépatocyte avec nécrose focale. Les taux de cholestérol et de triglycérides étaient plus élevés chez les faibles doses d'IGE traitées, mais ne différaient pas de manière significative des fortes doses d'EIG traitées et des témoins $(p<0.05)$.

Conclusion: L'extrait éthanoïque d'Irvingiagabonensis aux doses étudiées a provoqué une réduction du poids corporel chez la souris, ce qui est très évident à la faible dose, alors que le profil lipidique et les paramètres sanguins n'étaient pas affectés. Par conséquent, il peut être une herbe sans danger aux doses considérées. Les extraits ont provoqué une modification importante de l'histologie hépatique, qui s'est manifestée par une réduction des globules graisseux et une nécrose focale, gonflement des cellules.

Mots-clés: Progestérone, Obésité induite, Irvingiagabonensis, paramètres sanguins, profil lipidique.

\author{
*Auteur correspondant \\ Adesanya, O.A. \\ http://orcid.org/0000-0002-9960-399X \\ Email: oaesanya@gmail.com
}

\footnotetext{
${ }^{1}$ Department of Anatomy, Faculty of Basic Medical Sciences, Olabisi Onabanjo University, Ikenne Campus, Nigeria ${ }^{2}$ Department of Medical laboratory Sciences, College of Health Sciences, Ladoke Akintola University, Mercy Land, Osogbo, Nigeria.

3Department of Anatomy, Faculty of Biomedical Sciences, Kampala International University, Western Campus, Ishaka, Uganda.

4Department of Anatomcal Sciences, University of Abuja, Gwagwalada, Abuja, Nigeria.
} 


\section{INTRODUCTION}

Obesity is defined as having abnormal amount of body fat being 20-30\% over the ideal weight for age, sex and height. Millions of people around the world are facing obesity means suffering from an abnormal amount of body fat; being twenty to thirty percent over the ideal weight for age, sex and height (1). Aside from being a major cosmetic concern, obesity is a great risk factor for major serious medical conditions. Obesity is responsible for causing many health related problems, prostate enlargement, female infertility, uterine fibroids, several pregnancy disorders, cardiovascular disease, stroke and cancer (2).

Obesity means excessive weight which may also put a lot of stress on joints increasing the chances of arthritis It has become a problem of epidemic proportion in the West and Asia pacific $(1,2)$.

Aside from aggressive dieting and exercising, some herbal products may aid in raising metabolism or suppressing the appetite. Certain herbs may help in weight loss or preventing obesity but no legal treatment can completely cure obesity or result in significant weight loss without calorie intake reduction and exercise. But at the same time, these herbs have side effects $(3,4)$. Diverse hormones such as leptin, insulin, sex hormones and growth hormone greatly influence the appetite, metabolism, and body fat distribution and storage.[5] Females have a higher tendency for becoming obese due to the changes in the levels of sex hormones.[6] Estrogen and progesterone through action on their respective receptors possess a significant effect on substrate metabolism.[7]

Herbs like the aloe vera, astralagus, bee pollen, bladder wrack, brewer's yeast, cayenne, chitosan, chromium, dandelion, Ephedra, fennel, green tea, kelp, licorice, Siberian ginseng e.t.c. are beneficial in producing weight loss although some of these herbs can be harmful [8].

Irvingia is a genus of African and Southeast Asian trees in the family Irvingiaceae, sometimes known by the common names wild mango, African mango, or bush mango. They bear edible mango-like fruits, and are especially valued for their fat and protein-rich nuts. It is indigenous to the humid forest zone from the northern tip of Angola and other parts of Africa [9].

Many attempts have been made to correct obesity by designing a number of drugs such as orlistat, fibrates, and sibutramine.
However, they have been found to have severe side effects and are unaffordable $[10,11]$. Thus, the importance for development of herbal formulations has been overemphasized [12]. For example, a variety of natural products that are isolated plant compounds and crude plant extracts have been reported to cause bodyweight reduction. Some earlier studies have shown the inhibitory effects of Irvingia gabonensis on erythrocyte membrane adenosine triphosphatase in diabetics. It has also been shown that the seed and oil free seed powder has hypoglycemic effect and has been used for the treatment of type II diabetes [16-18]. The in vitro hepatoprotective effects of the crude extract of Irvingia gabonensis and some isolated metabolites have also been examined [19]. However, there is paucity of information on the effects of IG ethanolic extract on obesity till date. Therefore, this research was carried out to investigate some effects of ethanolic extract of Irvingia gabonensis on lipid parameters and histology of the liver on induced obesity in female albino mice.

\section{MATERIALS AND METHODS \\ Source of Plant (Seed)}

Irvingia gabonensis seed used in this research was obtained from Isiun market along Sagamu Abeokuta express road, Ogun State, Nigeria.

\section{Preparation of Extracts}

The extraction of Irvingia gabonensis was done through the use of Soxhlet apparatus using ethanol as a solvent. The seed was air dried for seven days then it was blended. $120 \mathrm{~g}$ of the blended Irvingia gabonensis was dissolved in $500 \mathrm{ml}$ of ethanol and it was left for 24 hours, after which it was filtered through a whatman-filter paper and the filtrate was used for the extraction process. The filtrate was concentrated using rotary flash vacuum evaporator. The extract was dried in vacuum drier. About $4.1 \mathrm{ml}$ of oil weighing about $3.9 \mathrm{~g}$ was recovered. The percentage recovery was $=3.9 / 120 \times 100=3.25 \%$

\section{Ethics Statement}

All experiments in obesity induced mice were carried out with permission of Faculty of Basic Medical Sciences of Olabisi Onabanjo University, and approved by the local ethical review committee on animal care of the University.

\section{Experimental Animals}

Fifteen female albino mice $(20-25 \mathrm{~g})$ 
were used in this study. Mice bred at central animal house of the Faculty of Basic Medical Sciences, Olabisi Onabanjo University, Ikenne were used in this experiment. Animals were housed in a standard controlled animal care facility in plastic cages with beddings to make them comfortable. The animals were maintained in a temperature-controlled room $\left(22^{\circ} \mathrm{C}-25^{\circ} \mathrm{C}\right.$, $45 \%$ humidity) on a $12: 12 \mathrm{~h}$ dark: light cycle. The animals were maintained under standard nutritional and environmental conditions throughout the experiment. All the experiments were carried out between 9:00-16:00 hours at ambient temperature. They were fed everyday with mashed rat feed which was obtained from Top-feed Nigeria, Limited and water ad-libitum so as to ensure proper digestion. They mice were acclimatized for 2 weeks.

\section{Grouping of Animals}

The mice were randomly distributed into three groups $(\mathrm{n}=5)$ as follows:

A: Control group: were given progesterone $(10 \mathrm{mg} / \mathrm{kgbw})$ and olive oil $10 \mathrm{ml} / \mathrm{kgbw}$ for 14days.

B: Low dose group: were given progesterone $(10 \mathrm{mg} / \mathrm{kgbw})$ and low dose of ethanolic extract of Irvingia gabonesis $(5 \mathrm{ml} / \mathrm{kg} \mathrm{bw})$ for 14 days

C: High dose: were given progesterone $(10 \mathrm{mg} / \mathrm{kgbw})$ and high dose of ethanolic extract of Irvingia gabonesis (10ml $/ \mathrm{kg} \mathrm{bw})$ for 14days

Progesterone vial contents were dissolved in olive oil and a dose of $(10 \mathrm{mg} / \mathrm{kg} \mathrm{bw})$ was administered subcutaneously in the dorsal neck region to mice for 14 days, control group received only the hormone without extract. Progesterone was given at a dose of $10 \mathrm{mg} / \mathrm{kg}$ body weight. The test extracts were administered $30 \mathrm{~min}$ before progesterone administration. The administration of the extract was carried out orally with the use of calibrated oral cannula and syringes (gavage). The extract and progesterone was given simultaneously daily basis to the mice in low dose, high dose and control received diluents olive oil for 14days, following the method of Chidrawar et al.. (20).

Method of Sacrifice: The weight of the animals were recorded on days $1,3,5,7,10$ and 14 . At the end of 2-weeks of treatment and induction, all the animals were sacrifice. The animals were placed in a glass jar with cotton wool soaked in chloroform one after the other and were allowed to sleep. The anterior portion of the genital area of the experimental animal was incised in the medial line which opened the internal organ under aseptic condition. The animals were cut open to locate the uterus, ovary, liver and the fat was collected. These organs blotted dry on filter paper and then carefully weighed on the sensitive weighing balance before they were put in the preservative $10 \%$ formol-saline solution. The blood samples were collected by cardiac puncture taken into plain bottles using the needle and syringes.

Phytochemical Studies: Phytochemical tests were carried out in the Pharmacognosy Department of ObafemiAwolowo College of Health Sciences, Sagamu to determine the presence of saponin, alkaloids, anthraquinone and glycosides.

Saponin: 1mg of Irvingia gabonesis flour (IG) was added to $10 \mathrm{ml}$ of water. It was shaken well and heated for $10 \mathrm{mins}$. It was later removed, shaken and filtered. $2.5 \mathrm{ml}$ of this filtrate was added to $7.5 \mathrm{ml}$ of water to make it up to $10 \mathrm{ml}$ altogether. After addition, it was shaken for 2 minutes. This is to test for the presence of saponin if foaming occurs.

Emulsifying test: 2 drops of arachis oil was added to solution observed above and shaken vigorously for few minutes.

Alkaloids: $1 \mathrm{~g}$ of sample was measured and $10 \mathrm{ml}$ of dilute $\mathrm{HCl}$ was added. It was then heated and boiled in water for $10 \mathrm{~min}$ and then filtered using filter paper $0.5 \mathrm{ml}$ of the filtrate is mixed with each of the solution below- Mayer's solution, 5\% $\mathrm{FeCl}_{3}$, Picric acid and Tannin solution.

Anthraquinone Test: $0.5 \mathrm{~g}$ of sample was put into a dry test tube. $5 \mathrm{ml}$ of chloroform was added and shaken for 5 minutes.Extract was filtered and filtrate was shaken with equal volume of $10 \%$ ammonia solution,

Glycosides: $2 \mathrm{ml}$ of sample was put in a test tube and 2-3 drops of Molisch reagent (10\% naphthol in alcohol) was added and then $1 \mathrm{ml}$ of conc. $\mathrm{H}_{2} \mathrm{SO}_{4}$ was poured into it.

Biochemical Assay: On 14th day the blood is collected from all the mice by Cardiac puncture method, and subjected for centrifugation at 3000 rpm for 15 mins. Blood was collected for the full blood count and the serum samples of all the blood samples were carefully collected and preserved for biochemical estimation of total cholesterol, LDL-C, HDL-C, Triglycerides using commercial kit (Randox Laboratories Ltd, UK). 
Histopathology of Liver: The tissues were fixed in $10 \%$ formol saline for 48 hours and processed routinely for paraffin embedding. Serial sections were obtained at $5 \mu \mathrm{m}$ thickness from a rotary microtome and subjected to the Haematoxylin and Eosin (H\&E) staining procedure.

Statistical Analysis: The results are expressed as Mean \pm SD. Comparisons between the treatment groups and positive control; positive control and control were performed by two-way analysis of variance (ANOVA) Bon-ferroni multiple comparison test. In all the tests the criterion for statistical significance was $\mathrm{P}<0.05$ (95\% level). The analysis was performed by using Graph Pad Prism 5.

\section{RESULTS}

Phytochemical analysis showed the absence of saponin, anthraquinone, alkaloid and presence of glycosides (Table 1). At the end of the experiment, the control group showed a steady weight gain throughout the study compared to the IGE high dose and low dose treated where the weight gain was not steady. (Figure 2). Treatment with IG ethanolic extract showed no significant effect on the cholesterol $(p<0.05)$, LDL $(p<0.05)$, HDL $(p<0.05)$ compared to the control (Figure $3)$. Administration of IGE did not show any significant effect on the $\mathrm{Hb}$ level, $\mathrm{PCV}$ and lymphocyte count $(\mathrm{P}<0.05)$ (figure 4$)$.

Histopathology: The central vein is evident in the image. In progesterone induced group the presence of fatty change was observed in the liver cells indicating progesterone is successfully responsible for the induction of the obesity. IGE $(5 \mathrm{ml} / \mathrm{kg})$ showed considerable reduction of fat globules. IGE $(10 \mathrm{ml} / \mathrm{kg})$ indicate increased focal necrosis and partial absence of fat globules and this extract shows significant decrease in the fat cells which were induced by progesterone [Figure 1].

\section{DISCUSSION}

The high incidence of obesity and the lack of safe pharmaceutical agents have fuelled an increase in researches related to anti-obesity drugs. Conventional drugs used for managing obesity including fibrates, sibutramine (an anorectic or appetite suppressant) and orlistat are not free from severe side effects [20-22] At present, because of dissatisfaction with high costs and potentially hazardous side effects, the potential of natural products for treating obesity is underutilized, and this may be an excellent alternative strategy for developing future and effective safe anti-obesity drugs. A variety of natural products, including crude extracts and isolated compounds from plants, can induce body weight reduction and prevent diet induced obesity. Therefore, they have been widely used in treating obesity.[21,22] A variety of natural products, including crude extracts and isolated compounds from plants, can cause body weight reduction, therefore they have been widely used in treating obesity[21 22].

Preliminary phytochemical analysis of Irvingia gabonensis ethanolic extract showed the presence of glycosides as the main constituent. Many studies have reported plants with phytochemicals like flavonoids, alkaloids, saponins, tannins, steroids, and phenols to have antiobesity effects. This phytochemical are said to interact and act in synergy to ensure weight lowering effects in studies (23). However most of these phytoconstituents were absent in the ethanolic extract of IG. Thus, the lack of weight lowering property observed in this study.

Progesterone administration used in obesity induction is reported to interrupt fat and carbohydrate metabolism which may reflect in the biochemical parameters such as blood glucose and lipid profile. Elevated progesterone level leads to gestational diabetes in pregnancy due to hyperphagia. Thus, in the current study there was no significant difference in the lipid profile HDL, LDL and TG values between the control (progesterone-alone) and the treated IGE $(5 \mathrm{ml} / \mathrm{kg}$ bw and $10 \mathrm{ml} / \mathrm{kg}$ bw) [24,25]. Progesterone modulated various biochemical parameters by stimulation of lipoprotein lipase, that hydrolyse dietary fat leading to enhancement of fat storage in the body, and thereby enhanced lipid profile.[26, 27]

The histopathological examination reveals the disruption of the liver cell due to effect of the inducing agent progesterone on the liver. The section of liver in progesterone treated group indicated distorted structures of functional unit of the liver, there was mild congestion and focal necrosis of hepatocytes. However, after IGE administration at $(5 \mathrm{ml} / \mathrm{kg}$ bw and $10 \mathrm{ml} / \mathrm{kgbw})$, the liver architecture was restored with reduction of fat globules collecting around the liver cells, this is similar to the findings of Damanyanthi et al., [27].

\section{CONCLUSION}

The study has shown that ethanolic extract of Irvingia gabonensis did not significantly reduced the body weight in mice, 
also the lipid profile and the blood parameters were not affected. However, the ethanolic extracts showed a good ameliorative on the liver histology, by reducing quantity of fat globules and focal necrosis, swelling of hepatic cells due to obesity induction. Hence, the ethanolic extract of IG does not exhibit antiobesity effects.

\section{REFERENCES}

1. Preventing and Managing the Global Epidemic. Geneva: World Health Organization; 2008.

2. World Health Organization. Obesity: preventing and managing the global epidemic. Report of a WHO consultation. World Health Organ Tech Rep Ser 2000; 894:1-12,1-253.

3. Lee J, Chae K, Ha J, Park BY, Lee HS, Jeong S, Kim MY, Yoon M (2008). Regulation of obesity and lipid disorders by herbal extracts from Morus alba, Melissa officinalis, and Artemisia capillaris in high-fat diet-induced obese mice. J. Ethnopharm. 115:263-270.

4. Bagri P, Ali M, Aeri V, Bhowmik M, Sultana S (2009). Antidiabetic effect of Punica granatum flowers: Effect on hyperlipidemia, pancreatic cells lipid peroxidation and antioxidant enzymes in experimental diabetes. Food Chem. Toxicol. 47: 62-69.

5. Klok MD, Jakobsdottir S, Drent ML. The role of leptin and ghrelin in the regulation of food intake and body weight in humans: A review. Obes Rev 2007;8:21-34.

6. Lovejoy J. the influence of sex hormones on obesity across the female life span. J Womens Health 1998;7:1247-56.

7. Boonyaratanakornkit V, Pateetin P. The role of ovarian sex steroids in metabolic homeostasis, obesity and postmenopausal breast cancer: Molecular mechanisms and therapeutic implications. Biomed Res 2015;1:1-13.

8. Luciano Mamede de Freitas Junior and Eduardo B de Almeida Jr (2017): Medicinal plants for the treatment of obesity: ethnopharmacological approach and chemical and biological studies Am J Transl Res 2017;9(5):2050-2064.

9. Spindler AA, Akosionu N. Gross Composition and Crude and Dietary Fiber Content of Soups Made with African Mango Seeds. Nutr Rep Int. 1985; 31:1165-1169.

10. Ngondi JL, Oben JE, Minka SR: The effect of Irvingia gabonensis seeds on body weight and blood lipids of obese subjects in Cameroon. Lipids Health Dis 2005, 4:12.

11. Julius E Oben, Judith L Ngondi, Claudia N Momo, Gabriel AAgbor and Caroline S Makamto Sobgui; The use of a Cissus quadrangularis/Irvingia gabonensis combination in the management of weight loss: a doubleblind placebo-controlled study. Lipids in Health and Disease 2008, 7:12.

12. Judith L Ngondi1, Blanche C Etoundi, Christine B
Nyangono, Carl MF Mbofung and Julius E Oben: IGOB131, a novel seed extract of the West African plant Irvingia gabonensis, significantly reduces body weight and improves metabolic parameters in overweight humans in a randomized double-blind placebo controlled investigation. Lipids in Health and Disease 2009, 8:7.

13. Lean ME. How does sibutramine work? Int J Obes Relat Meta Disord 2001;25 Suppl 4:S811.

14. Tziomalos K, Krassas GE, Tzotzas T. The use of sibutramine in the management of obesity and related disorders: An update. Vasc Health Risk Manag 2009;5:441-52.

15. Rohit Gundamaraju, Sartaj Banu Mulaplli, Dr.Ramesh.C : Evaluation of Anti-Obesity Activity of Lantana camara Var Linn. by Progesterone Induced Obesity on Albino Mice: International Journal of Pharmacognosy and Phytochemical Research , 2012; Vol-4, Issue 4, pp. 213-218

16. Damayanthi Dalu1, Satyavati Dhulipala, Jamunakar Kuncham. Anti-obesity activity of Vitis vinifera by butter and progesterone induced models Journal of Pharmacy Research Vol :Issue 32018

17. Moro CO, Basile G. Obesity and medicinal plants. Fitoterapia 2000; 71 Suppl 1: S73-82.

18. Vasudeva N, Yadav N, Sharma SK. Natural products: a safest approach for obesity. Chin J Integr Med 2012; 18: 473-480.

19. Chidrawar Vijay R., Krishnakant N. Patel, Navin R. Sheth, Shruti S. Shiromwar, and Piyush Trivedi. Antiobesity effect of Stellaria media against drug induced obesity in Swiss albino mice. Ayu. 2011 Oct-Dec; 32(4): 576-584.

20. Tziomalos K, Krassas GE, Tzotzas T. The use of sibutramine in the management of obesity and related disorders: An update. Vasc Health Risk Manag. 2009;5:441-52.

21. Moro CO, Basile G. Obesity and medicinal plants. Fitoterapia. 2000;71:S73-82.

22. Rayalam S, Della-Fera MA, Ambati S, Yang JY, Park HJ, Baile CA. Enhanced effects of 1, 25(OH) 2D3 plus genistein on adipogenesis and apoptosis in 3T3-L1 adipocytes. Obesity (Silver Spring) 2008;16:539-46

23. Abinaya K. R. and Pavitra, R. "Management of obesity and its related disease by herbal drugs," International Journal of Ayurvedic andHerbalMedicine, vol. 4, no. 3, pp. 1470-1479, 2014.

24. Sung YY, Kim DS, Kim HK. Akebia quinata extract exerts anti-obesity and hypolipidemic effects in high-fat diet-fed mice and 3T3-L1 adipocytes. J Ethnopharmacol 2015; 168: 17-24.

25. Karakaya S. Bioavailability of phenolic compounds. Crit Rev Food Sci Nutr 2010; 44: 453-464.

26. Jianghao Sun and Pei Chen: UHPLC/HRMS Analysis of African Mango (Irvingia gabonensis) Seeds, Extract and Related Dietary Supplements. 
JAgric Food Chem. 2012 ; 60(35): 8703-8709.

27. Badimon, L., Vilahur, G., \& Padro, T. (2010). Nutraceuticals and atherosclerosis: human trials. Cardiovascular Therapeutics, 28(4), 202-15.

28. Mulvihill, E. E., \& Huff, M. W. (2010). Antiatherogenic properties of flavonoids: implications for cardiovascular health. Canadian Journal of Cardiology, 26(Suppl A), 17A-21A

29. Rodrigues, A. S., Perez-Gregorio, M. R., GarciaFalcon, M. S., \& Simal-Gandara, J. (2009). Effect of curing and cooking on flavonols and anthocyanins in traditional varieties of onion bulbs. Food Research International, 42(9), 13311336.

30. Dilpesh J, Preeti B, Akansha S, Mitali G. Evaluation of anti-obesity effect of fattolin, a polyherbal formulation in progesterone induced obesity in mice. Ind J Pharma Edu Res 2016; 50(3): 391-6.

31. Boonyaratanakornkit V, Pateetin P. The role of ovarian sex steroids in metabolic homeostasis, obesity, and postmenopausal breast cancer: Molecular mechanisms and therapeutic implications. Biomed Res Int 2015;2015:140196.

32. Shirling D, Ashby J, Baird J. Effect of progesterone on lipid metabolism in the intact rat. J Endocrinol 1981;90:285-94.

33. Damayanthi Dalu, Satyavati Dhulipala, Jamunakar Kuncham:Anti-obesity activity of Vitis vinifera by butter and progesterone induced models, Journal of Pharmacy Research | Vol 12 Issue 32018 
Table1: Phytochemical Analysis of Irvingia gabonensis

\begin{tabular}{ll}
\hline Phytochemicals & Results \\
\hline Saponin & Negative \\
Glycoside & Positive \\
Anthraquinone & Negative \\
Alkaloid & Negative \\
\hline
\end{tabular}

The ethanolic extract of the seed of Irvingia gabonensis were found to contain only glycosides. All the other phytochemicals tested for were negative- saponin, anthraquinone, and alkaloid.

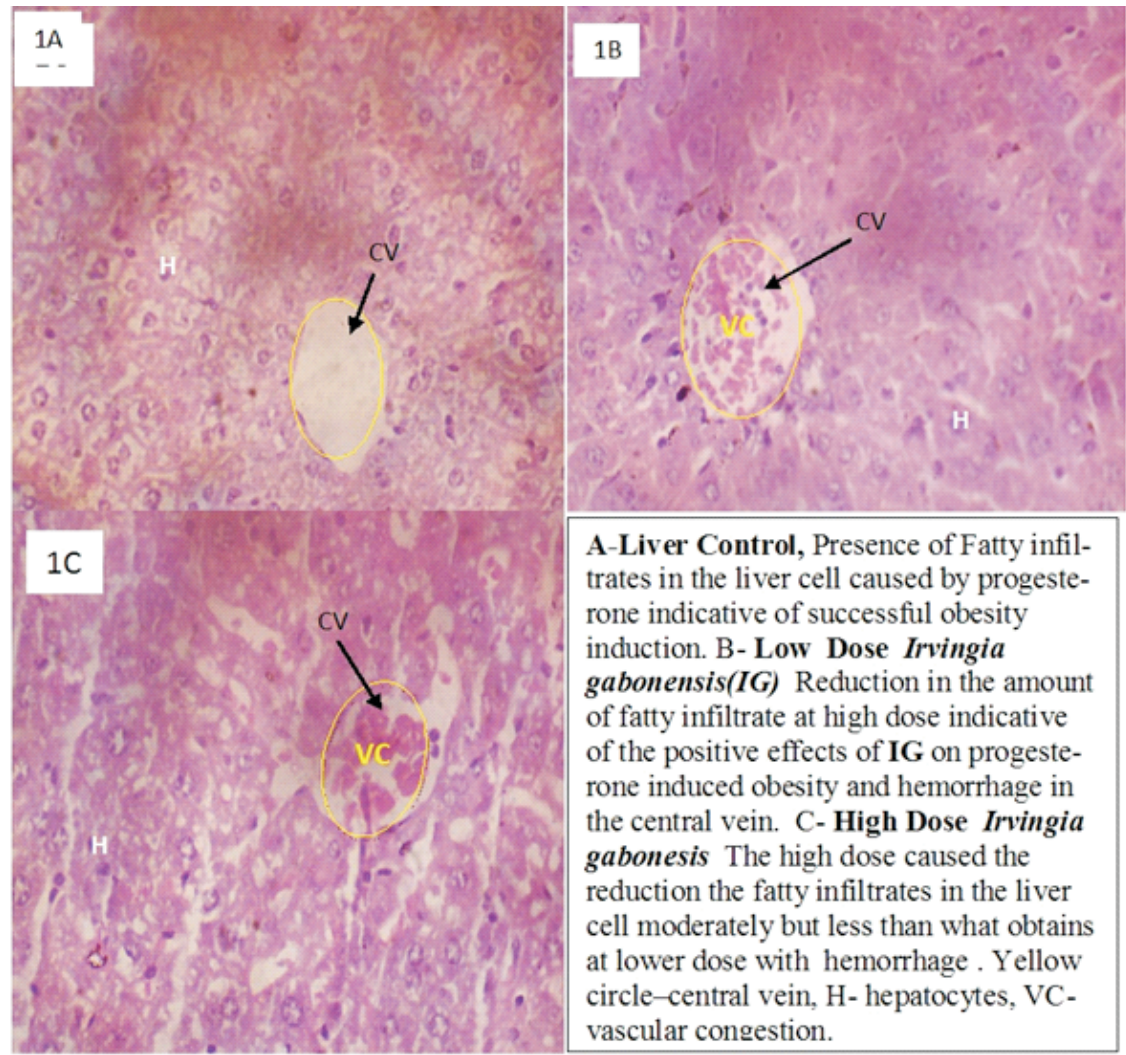

H\& E STAIN (X400)

FIGURES 1A-C SHOWING THE HISTOARCHITECTURE OF THE LIVER OF RATS FOLLOWING EXPOSURES TO IRVINGIA GABONENSIS ETHANOLIC EXTRACT. 


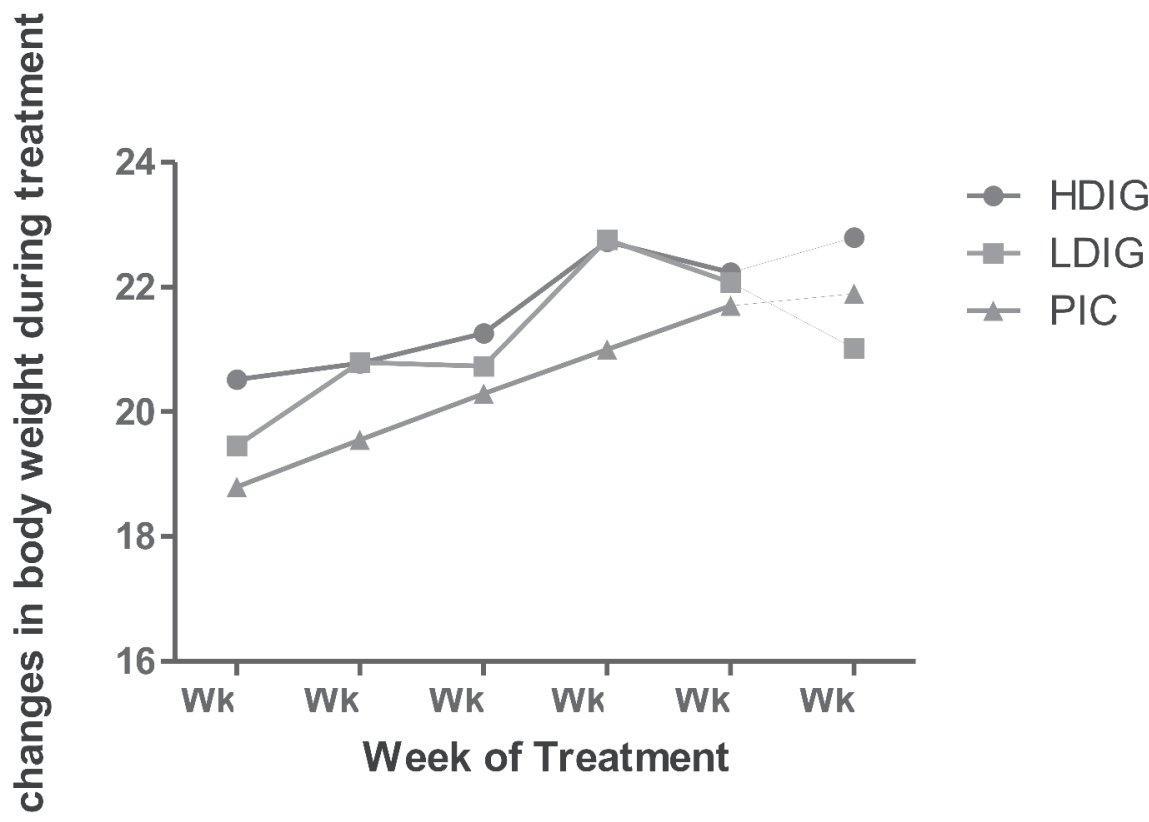

Figure 2: Effect of IG treatment on body weight

The treatment at high dose caused a rapid gain in the animal body weight; the herbal intervention at low dose reduced the weight of the mice but not significantly $(\mathrm{P}>0.05)$ compared to the control.

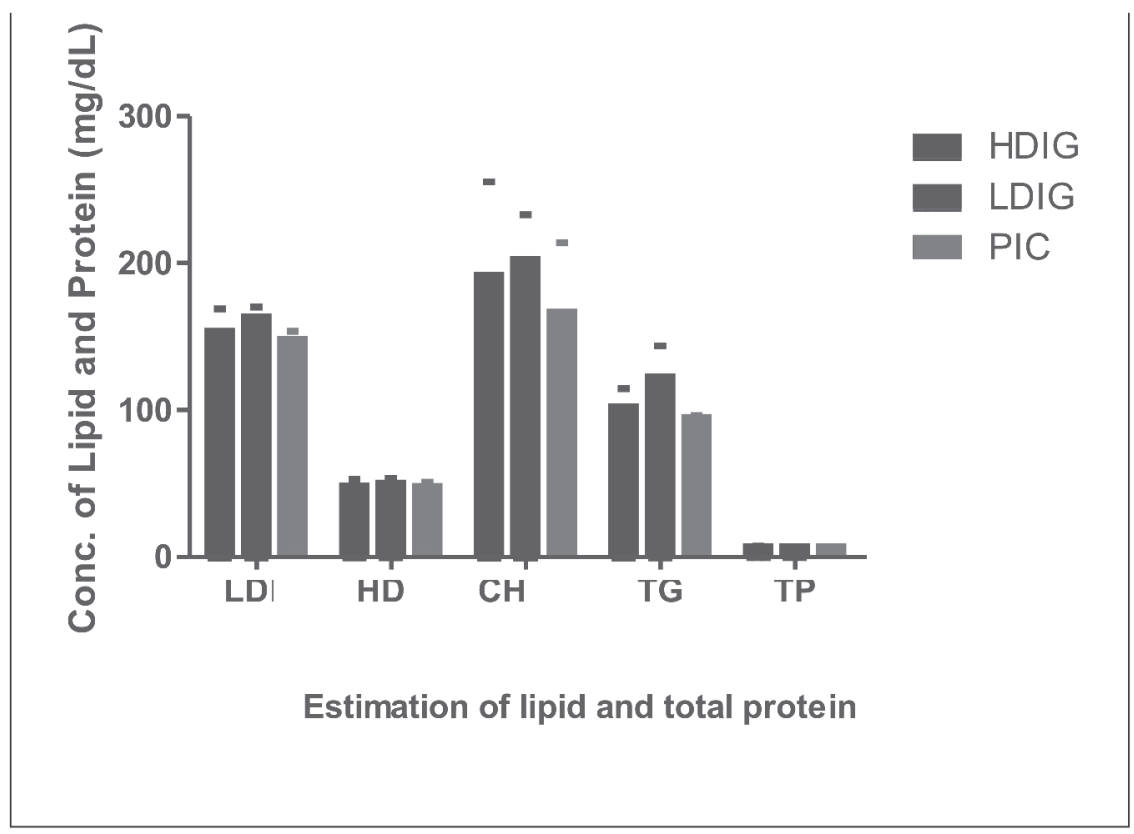

Figure 3: Ethanolic extract Irvingia gabonensis produced no significant effect $(\mathrm{P}>0.05)$ on the lipid parameters assayed in this study both at low and high dose. 


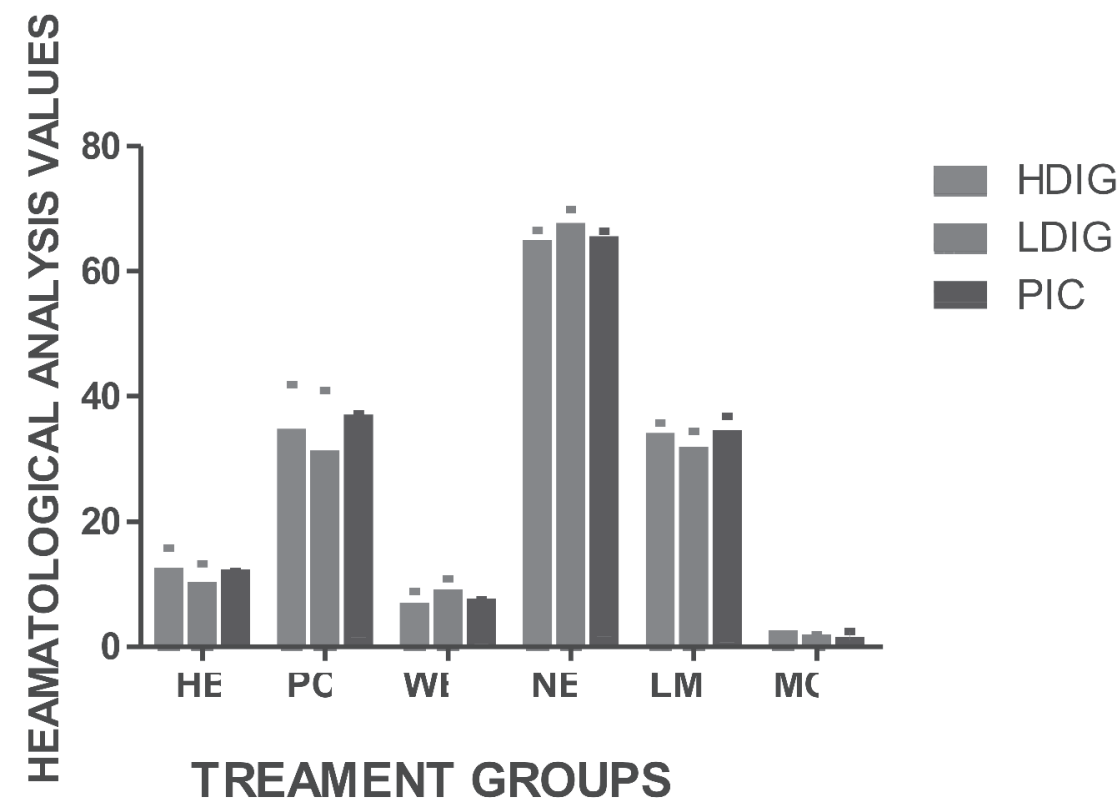

Figure 4: Ethanolic extract Irvingia gabonensis showed no significant effect $(\mathrm{P}>0.05)$ on the blood parameters measured in this study either at low or high dose. 